\title{
Portal venous gas after a caudal block
}

\author{
Tatsuya Fujikawa, ${ }^{1,2}$ Seiyo Murai ${ }^{1}$
}

'Seikeikai Hospital, Sakai, Japan

${ }^{2}$ Mitoyo General Hospital, Kan-onji, Japan

\section{Correspondence to} Dr Tatsuya Fujikawa, tfujikawa-gi@umin.ac.jp

Accepted 3 June 2014

\section{-}

To cite: Fujikawa T, Murai S. BMJ Case Rep Published online: [please include Day Month Year] doi:10.1136/bcr-2014205381

\section{DESCRIPTION}

A 72-year-old woman with lumbar spinal stenosis, old cerebral infarction and hypertension presented with sudden onset of upper abdominal pain following caudal block carried out for the evaluation of lumbar spinal stenosis in another centre. Abdominal examination revealed hypoperistalsis and epigastralgia with no rebound tenderness. The laboratory results indicated leucocytosis (white cell count, $10800 / \mu \mathrm{L})$. Contrast-enhanced CT (CECT) revealed gas within the portal venous system (figure 1A, B) and intramural/extramural gas of the ileum (pneumatosis intestinalis; figure 2, arrows). However, the ileal bowel loops showed normal wall enhancement on CECT ruling out bowel gangrene. The faecal culture was negative for pathogens. In view of absent sinister abdominal signs of bowel gangrene the patient was conservatively managed with nil per os, intravenous antibiotics and heparin. The patient showed clinical improvement in symptoms with day 3 CT study showing complete regression of portal venous gas (PVG) and pneumatosis intestinalis.

PVG is a rare condition often associated with mesenteric ischaemia and bowel necrosis, with a potentially fatal outcome. ${ }^{1}$ PVG owing to iatrogenic causes has been detected following medical procedures, including double-contrast barium

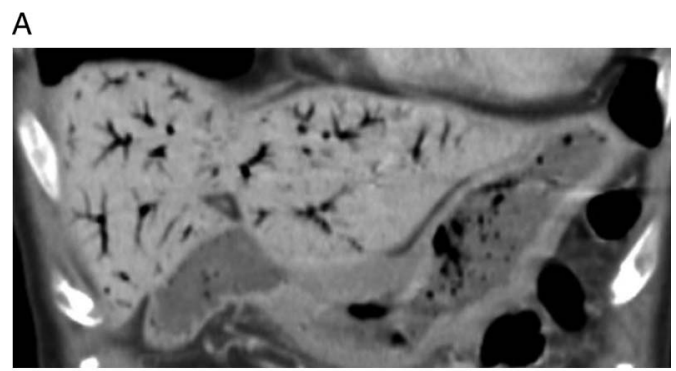

B

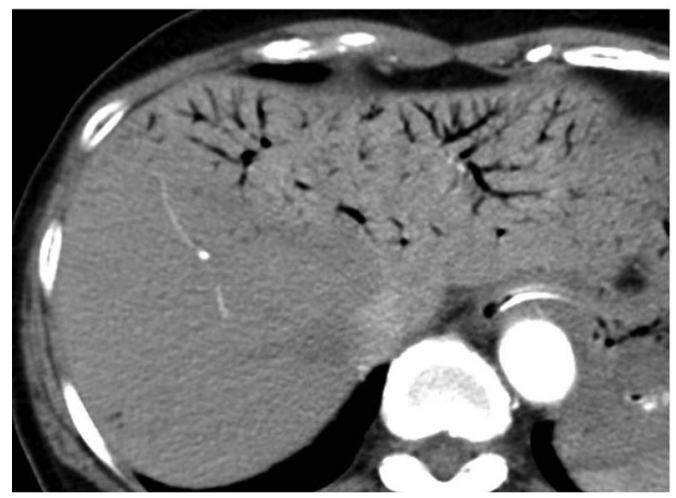

Figure 1 (A and B) Contrast-enhanced CT scan showing gas throughout the portal venous system.

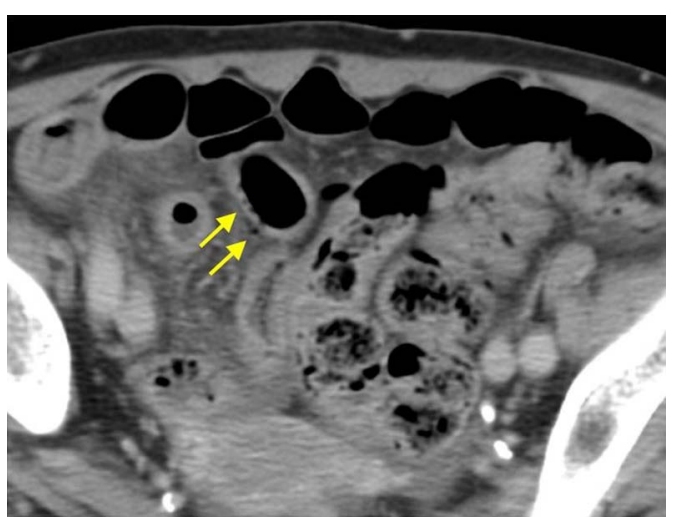

Figure 2 Intramural/extramural gas of the ileum.

enema, colonoscopy, endoscopic sphincterotomy, radiofrequency ablation ${ }^{2}$ and lumbar puncture. ${ }^{3}$

On the basis of her clinical course and images, intestinal ischaemia and PVG possibly occurred from air entry into the epidural venous plexus, namely Batson's venous plexus during the caudal block.

Batson's venous plexus is a paraspinal venous system composing of a network of veins that are longitudinally orientated. ${ }^{4}$ It interconnects with pelvic venous structures, femoral and iliac veins, and the inferior and superior vena cava, and also with portal vein. ${ }^{4}$ Unlike the other veins of the body, the veins of the Batson's venous plexus are valveless and are not protected against variations of abdominal or thoracic pressures. ${ }^{4}$

This case demonstrates that a caudal block, which is mostly associated with the minor complications, ${ }^{3}$ could cause intestinal ischaemia and even PVG. It alerts physicians to the necessity for close monitoring of the patient after a caudal block. This case illustrates that PVG with pneumatosis intestinalis could respond to conservative management especially in patients with absent abdominal sign of bowel ischaemia.

\section{Learning points}

Portal venous gas is a rare condition associated with mesenteric ischaemia and bowel necrosis, with a potentially fatal outcome.

- A caudal block, which is mostly associated with the minor complications, could cause intestinal ischaemia and even portal venous gas. 
Acknowledgements The authors gratefully acknowledge Dr Juichi Tsushima for diagnostic imaging.

Contributors TF wrote the manuscript and contributed to the discussion. SM contributed to the discussion.

Competing interests None.

Patient consent Obtained.

Provenance and peer review Not commissioned; externally peer reviewed.

\section{REFERENCES}

1 Liebman PR, Patten MT, Manny J, et al. Hepatic-portal venous gas in adults: etiology, pathophysiology and clinical significance. Ann Surg 1978;187:281-7.

2 Pua U. Percutaneous liver biopsy: a cause of hepatic portal venous gas. Can Med Assoc J 2010;182:E861.

3 Karaosmanoğlu D, Oktar SO, Araç M, et al. Portal and systemic venous gas in a patient after lumbar puncture. Br I Radiol 2005;78:767-9.

4 Batson OV. The function of the vertebral veins and their role in the spread of metastases. Ann Surg 1940;112:138-45.

Copyright 2014 BMJ Publishing Group. All rights reserved. For permission to reuse any of this content visit http://group.bmj.com/group/rights-licensing/permissions.

BMJ Case Report Fellows may re-use this article for personal use and teaching without any further permission.

Become a Fellow of BMJ Case Reports today and you can:

- Submit as many cases as you like

- Enjoy fast sympathetic peer review and rapid publication of accepted articles

- Access all the published articles

- Re-use any of the published material for personal use and teaching without further permission

For information on Institutional Fellowships contact consortiasales@bmjgroup.com

Visit casereports.bmj.com for more articles like this and to become a Fellow 